\title{
Eğitime Erişim, Yoksulluk ve Formel/Enformel İş- gücü Olarak Üniversite Gençliği: “İstihdam İçin mi Eğitim? Eğitim İçin mi İstihdam?"
}

\author{
DOI: $10.26466 /$ opus.354859 \\ * \\ Hasan Hüseyin Aygül* \\ *Dr. Öğr. Ü., Akdeniz Üniversitesi, Edebiyat Fakültesi, Antalya/Türkiye \\ E-Posta: hasanhuseyinaygul@akdeniz.edu.tr ＯRCID: 0000-0002-0701-5067
}

Öz

Yükseköğretim öğrencilerinin yeterli ekonomik kaynaklara sahip olmaması, ayrıca kredi, burs, yurt gibi çeşitti destek mekanizmalarının yetersiz kalması nedeniyle; beslenme, barınma, ulaşım, să̆llk gibi çeşitli alanlardaki temel ihtiyaçların karşılayamadığı ve eğitim yaşamların sürdürebilme noktasında problemler yaşadığı gözlenmektedir. Dolayısıyla eğitim sürecine dâhil olmak kadar eğitimi sürdürebilmek de önemli bir meseledir. Bu durum "istihdam için mi eğitim?" yoksa "eğitim için mi istihdam?" sorusunu akla getirmektedir. Yoksul öğrenciler için ikinci soru birincisine göre anlamlı durmaktadır. Bu çalışma üniversite gençliğini; eğitime erişim, yoksullukla mücadele ve formel/enformel işgücü kullanımı üzerinden ele almaktadır. Buna göre tarım, imalat, inşaat, turizm gibi emekyoğun sektörlerde; güvencesiz, düşük ücretli, geçici/mevsimlik işgücü olarak formel/enformel bir şekilde istihdam edilen üniversite öğrencileri araştırmanın örneklemini oluşturmaktadır. Buradan hareketle üniversite öğrencilerinin formel/enformel olarak istihdam edildikleri alanların ve istihdam koşullarının tespit edilmesi, ayrıca yoksulluk ve eğitime erişim arasındaki ilişkinin ortaya konulması amaçlanmıştır. Araştırma, Akdeniz Üniversitesi'nde öğrenim görmekte olan 22 öğrenciyle gerçekleştirilmiştir. Çalışmada veri toplama aracı olarak yarı yapılandırılmış görüşme formu kullanılmıştır. Elde edilen veriler içerik analizi yöntemiyle değerlendirilmiştir. Sonuç olarak üniversite öğrencilerinin; eğitim yaşamlarmı sürdürebilmek, "mutlak" velveya "göreli" yoksulluklarmı telafi etmek, ayrica diğer gençler gibi tüketime dâhil olma beklentisiyle formel/enformel sektörlerde güvencesiz, düşük ücretli, geçici/mevsimlik işgücü olarak çalışmak zorunda oldukları belirlenmiştir.

Anahtar Kelimeler: Eğitim, Gençlik, İstihdam, Yoksulluk.

OPUS (c) Uluslararası Toplum Araştırmaları Dergisi-International Journal of Society Researches ISSN:2528-9527 E-ISSN : 2528-9535

http://opusjournal.net 


\title{
Access to Higher Education, Poverty and the Univer- sity Youth as Formal/Informal Workforce: "Educa- tion for Employment? Or Employment for Educa- tion?"
}

\begin{abstract}
It is observed that university students have failed to meet their basic needs in various fields such as nourishment, accommodation, transport and healthcare and have confronted some problems in maintaining their student life owing to the financial inabilities, as well as the lacking support mechanisms such as student loans, scholarship and dormitory facilities. Consequently, it is a matter of fact that maintaining the ongoing higher education process for students is as important as getting involved into academic life itself. This situation is redolent of the following questions raised as such; "Education for Employment? Or Employment for Education?" For those needy students, the latter question seems more reasonable than the former one. This study deals with the university youth in terms of their access to higher education, their struggling against poverty and their utilisation as formal/informal workforce. Accordingly, the university youth that is formally/informally employed as uninsured, low-paid, temporary/seasonal workforce in the labour-intensive sectors such as agriculture, manufacture, construction and tourism constitutes the sample of this research. Proceeding from this point, the determination of the fields the students formally/informally employed in and the related employment conditions, as well as the introduction of the relationship between poverty and access to higher education are aimed at this study. The research has been carried out with 22 students who study at the Akdeniz University. During this study, semi-structured interview form has been utilised as a means for data collection. The data obtained meanwhile have been evaluated by means of the content analysis. As a consequence, it has been determined that the university students had to work in order to compensate their "absolute" and/or "relative" poverty and to maintain their education life as being uninsured, low-paid and temporary/seasonal workforce in the sector just like the other youths that have the expectation of getting involved in the consumption circle.
\end{abstract}

Keywords: Education, Employment, Poverty, Youth

OPUS (c) Uluslararası Toplum Araştırmaları Dergisi-International Journal of Society Researches ISSN:2528-9527 E-ISSN : 2528-9535

http://opusjournal.net 


\section{Giriş}

Gençlik; çocukluk ve yetişkinlik arasındaki "bir geçiş dönemi", "yetişkinlik durumuna nihai bir varış" ya da diğer yaş aralıklarında olduğu gibi "yaşamın bir evresi" olarak kabul edilmektedir. Gençlik araştırmalarında pratik bir amaç olarak biyolojik/psikolojik sınıflandırma yapılarak; yaşın anlamı, yaşlanma deneyimi ve yaşlanma süreci ile ilgili nesnel olarak ölçülebilen ve bu şekliyle veri sağlanmasını mümkün kılabilecek özellikler temel alınmaktadır. Gençlik döneminin toplumsal, kültürel ve tarihsel şartlara bağlı olarak değişkenlik gösteren bir olgu olduğu yönünde tartışmalar da bulunmaktadır. Gençlik, kuşaklar bağlamında değerlendirildiğinde ise aynı toplumsal düzlem içinde farklı anlamlara sahip olabilmektedir. Dolayısıyla gençlik, ilişkisel bir kavramdır (Wyn ve White, 1997, s.9-11).

Nesnel bir sınıflandırma yapabilmek amacıyla, 15-24 yaş aralığı, genç nüfus olarak kabul edilmektedir. Türkiye'de gerçekleştirilen gençlik araştırmaları ve TÜİK (Türkiye İstatistik Kurumu) bu yaş aralığını esas almaktadır. "Üniversite gençliği" dediğimizde ise bunun 18-24 yaş aralığına karşılık gelebileceğini belirtebiliriz. Genç olarak ifade edebileceğimiz kişileri homojen bir grup olarak nitelendirmek mümkün değildir. Benzer şekilde üniversite gençliği de sosyal ve kültürel tabanlarından yaşam tarzlarına ve tüketim kalıplarına, ayrıca dünya görüşü ayrılıklarından politik duruşlarına kadar farklı kategorilere karşılık gelmektedir.

Sosyoloji alanında gerçekleştirilen gençlik araştırmaları söz konusu farklılıkları da dikkate alarak; istihdam, yoksulluk, engellilik, şiddet, dezavantajlı gruplar, bağımlılık, toplumsal cinsiyet, sosyal dışlanma, eğitim, fırsat eşitliğii, sosyal adalet, yaşam tarzı, tüketim kalıpları, boş zaman değerlendirmesi gibi olgular ve kavramlar üzerinden "genç bireyleri" ele almaktadır. Bu çalışma ise hem eğitimde hem de istihdamda olan üniversite gençliğini konu edinmektedir.

Eğitime erişim ve eğitim sürecinde kalma ile ilgili yapılan çalışmalar birbiriyle ilişkili iki boyuta odaklanmaktadır: Birinci boyut, eğitim sisteminin işleyişiyle ilgilidir. Buna göre eğitimciler, okullar, sınıflar, ders materyalleri gibi pek çok alandaki ve genel anlamda eğitimdeki fırsat eşitliği 
gibi konulardaki yetersizliklerin, aksaklıkların veya çarpıklıkların, eğitime erişim ve istihdam ilişkileri çerçevesinde ortaya çıkardığı eşitsizliklere vurgu yapılmaktadır. Yaygın kabule göre kitlesel eğitim modern zamanın temel özelliklerinden biridir ve amacı gençleri yetişkinliğe hazırlamaktadır. Farklı bir bakış açısına göre de gençleri, istihdam ilişkileri içine dâhil etme sürecidir. Günümüzde kitlesel eğitimin genişliği ve süresi, gençler için yetişkinliğe geçiş sürecinin yeniden yapılandırılmasını zorunlu kilmaktadır. Ancak mevcut eğitim sistemleri neredeyse bir asır önceki anlayışla varlığını sürdürmektedir. Üstelik eğitim sisteminin genişletilmesi sonucu, genç bireyler yetişkinliğe hazırlanma noktasında yeterli kaynaklardan yoksun olabilmektedir. Yani mevcut eğitim sistemleri ve araçları genç bireyleri, gelişen ve esnekleşen işgücü piyasasına uygun niteliklerde hazır hale getirme noktasında başarısızdır (Grant ve Furstenberg, 2007). Görüldüğü üzere birinci boyut eğitim sisteminin işleyişindeki bir takım olumsuz durumların yoksulluğa, işsizliğe, sosyal dışlanmaya vb. sebep olduğunu belirterek, çözümü eğitim sisteminin yeniden yapılandırılmasında görmektedir.

İkinci boyut ise toplumsal sistemdeki yapısal eşitsizliklerin eğitim sürecini etkilediğini iddia etmektedir. Eğitim sürecindeki eşitsizliklerin sosyal olana dair her alanda yeni eşitsizlikler ürettiği bilinmektedir, ancak yapısal eşitsizliklerin de eğitime erişimi engellediği görülmektedir. Buna göre ailenin sahip olduğu kültürel (eğitim) ve ekonomik (gelir) sermaye türü ile mekânsal özellikler (kır-kent ya da bölgesel eşitsizlikler) öğrencinin aldığı eğitimin süresini, niteliğini ve nihayetinde hangi istihdam alanında ve koşullarda çalışacağını etkilemektedir. Bu bağlamda eğitimcilerin ve politika yapıcıların görüşleri ve stratejileri farklılaşmaktadır. Eğitimciler, eğitimde sosyal adalete odaklanarak, sosyoekonomik ve kültürel şartlar bakımından dezavantajlı bireylere yönelmekte ve bu noktada mikro ölçekli öneriler geliştirmektedir. Politika yapıcılar ise konuyu istihdam koşullarına uygun bireyler yetiştirme ve bu hususta makro ölçekli politikalar üretme bağlamında değerlendirmektedir (McPake ve Bhatti, 1999, s.553, 558).

Araştırma ikinci boyuttan hareketle üniversite öğrencilerinin eğitim süreçlerindeki istihdam ilişkilerini ele almaktadır. Yükseköğretim öğrencilerinin yeterli ekonomik kaynaklara sahip olmaması, ayrıca kredi, burs, yurt gibi çeşitli destek mekanizmalarının yetersiz kalması nedeniyle; 
beslenme, barınma, ulaşım, sağlık gibi çeşitli alanlardaki temel ihtiyaçlarını karşılayamadığı ve eğitim yaşamlarını sürdürebilme noktasında problemler yaşadığı gözlenmektedir. Dolayısıyla eğitim sürecine dâhil olmak kadar eğitimi sürdürebilmek de önemli bir meseledir. Bu durum "istihdam için mi eğitim?" yoksa "eğitim için mi istihdam?" sorusunu akla getirmektedir. Yoksul öğrenciler için ikinci soru birincisine göre anlamlı durmaktadır. Araştırmada; tarım, imalat, inşaat, turizm gibi emek-yoğun sektörlerde; güvencesiz, düşük ücretli, geçici/mevsimlik işgücü olarak formel/enformel bir şekilde istihdam edilen üniversite öğrencilerinin istihdam edildikleri alanların, istihdam koşullarının ve çalışma gerekçelerinin tespit edilmesi, ayrıca yoksulluk ve yükseköğretime erişim arasındaki ilişkinin ortaya konulması amaçlanmıştır. Bunun için öncelikle ulusal ve uluslararası düzeydeki istatistiki verilerden ve bu alanda gerçekleştirilmiş çalışmalardan hareketle Türkiye'deki gençlerin; eğitim, istihdam ve yoksulluk görünümleri değerlendirilecek, akabinde Akdeniz Üniversitesi öğrencileriyle gerçekleştirilen görüşmelerden elde edilen veriler içerik analizi yöntemiyle çözümlenecektir.

\section{Üniversite gençliğinin eğitime erişimi ve eğitimde kalma problemleri}

Eğitimden beklenen sadece "kültürel mirasın aktarılması" ya da "bireyin sosyalizasyonu" değil, aynı zamanda esnek, hareketli ve değişen işgücü piyasasına nitelikli işgücü sağlamasıdır. Eğitim düzeyi, kişinin toplumsal konumunun, dolayısıyla sahip olduklarının ve elde edeceklerinin de bir göstergesidir. Türkiye gibi istihdam alanlarının dar olduğu, ayrıca özel sektörün kamu sektörüne göre görece güvencesiz ve düşük ücretli olduğu ülkelerde, diploma çeşitli mevkilere ulaşabilmenin de başlıca aracıdır. Oysa toplumsal eşitsizliklerin varlığ 1 "herkes için eğitim" söylemini zayıflatmaktadır. Gelişmiş ya da gelişmekte olan ülkeler fark etmeksizin eğitimdeki eşitsizlikler giderek büyümektedir. Diğer bir ifadeyle eğitimdeki eşitsizlikler, toplumsal eşitsizlikleri yeniden üretmektedir ki bunun tersi daha anlamlıdır: Eğitim sisteminin yerleşik düzenin yeniden üretilmesine, yani toplumsal düzenin ideolojik olarak meşruiyetini üretmesine katkıda bulunur (Bourdieu ve Passeron, 2005, s.255). Nihayetinde eğitim sisteminin temel sorunu, "herkes için eğitim” ilkesinin, "ekonomik 
ve kültürel sermayenin hacmine ve kompozisyonuna göre eğitim" anlayışına dönüşmesidir.

Türkiye'deki gelir eşitsizliği, ücretli eğitim mekanizmalarının varlığı (özel okullar veya vakıf üniversiteleri gibi), bölgesel farklılıklar, toplumsal cinsiyet eşitsizliği, yoksulluk gibi göstergeler dikkate alındığında, eğitimde fırsat eşitliğinin olduğunu ifade etmek zorlaşır. Buna karşın 12 yıllık kademeli zorunlu eğitimin ücretsiz olması, devlet tarafından öğrencilere ücretsiz verilen ders materyalleri ve özel okullara gidecek öğrencilere verilen teşvik primleri sosyal refah devleti anlayışı çerçevesinde değerlendirilebilecek eğitim politikalarıdır. Ayrıca yükseköğretim sürecinde örgün eğitimde olan öğrencilerden alınan katkı payı ve harç uygulamasının kaldırılması; yurt sayısı, burs ve kredi miktarlarının artırılması da bu kapsamda değerlendirilebilir.

Türkiye'deki net okullaşma oranlarına bakıldığında, OECD ortalamalarının üzerinde olduğu görülmektedir. Buna göre son yıllardaki düşüşe rağmen 2015-2016 yılına ait ilkokulda net okullaşma oranı \%94,84; ortaokulda \%94,39; ortaöğretimde ise \%79,76'dır (TÜİK, 2017). Yükseköğretimdeki net okullaşma oranı ise 2015-2016 yılı itibariyle \%40,9'dur (TÜİK, 2016). 12 ylllık kademeli zorunlu eğitime geçiş ile üniversite ve öğrenci sayısındaki artışlar (2017 itibariyle 104 devlet 71 vakıf olmak üzere 185 üniversitede 6 milyon 627 bin 505 kişi) net okullaşma oranlarını önemli ölçüde artırmıştır.

Avrupa Komisyonu tarafından hazırlanan “Türkiye 2011 Yılı İlerleme Raporu", Türkiye'nin eğitim, mesleki eğitim ve gençlik konularında AB müktesebatı ve standartları hususunda uyum sağlamaya devam ettiğini bildirmiştir, ancak gerek cinsiyet eşitsizliğinin devam etmesi gerekse üniversitelerdeki öğretim kadrosunun sayısı ve altyapı bakımından farklılıklar göstermesi bakımından eksikliklerinin olduğu da vurgulanmıştır (2011, s.97-98). “Türkiye 2013 Y11ı İlerleme Raporu”nda ise Türkiye'nin yükseköğretime erişimde ilerleme kaydettiği, ancak $\mathrm{AB}$ ortalamasının altında olduğu ifade edilmiştir (2013, s.70).

Türkiye'de okula kayıt ve devam oranlarının; aile yapısı (gelir, ebeveyn eğitim düzeyi ve ailedeki çocuk sayısı bakımından), cinsiyet ve yerleşim yeri (gerek bölge, gerekse kırsal alan ya da kent olması bakımından) gibi koşullarla istatistiksel olarak anlamlı olduğunu ortaya koymaktadır. Örneğin Doğu'da ve özellikle kırsal alanlarda ikamet eden kız 
çocuklarının, erkek çocuklara göre okula gitme oranı daha düşüktür. Yine okula kayıt olma olasılığı ya da okulu erken bırakma olasılığı; ailenin gelir seviyesi, eğitim düzeyi ve çocuk sahibi olma koşullarına bağlı olarak kız çocukları üzerinde daha belirleyici olabilmektedir (Ferreira ve Gignoux, 2010, s.5, 9). Ailelerin sahip olduğu "kültürel ve ekonomik sermayenin" hacmi ve kompozisyonu kadar toplumsal cinsiyet ve mekânsal koşulların da, eğitime erişimi ve eğitimde kalma süresini belirlediği görülmektedir.

Konuyla ilişkili bir diğer problem, ne eğitimde ne de istihdamda olmayan genç bireylerin sayısının (NEET-Not in Education, Employment, or Training) her geçen gün artış göstermesidir. Türkiye' de NEET oranı \%30 ile OECD ülkeleri içinde en yüksek seviyededir. Ancak 12 yıllık kademeli zorunlu eğitime geçişle birlikte, son on yılda büyük bir iyileşmenin olduğu da belirtilmelidir. Kadınlar için NEET oranı, OECD ülkelerinde ortalama \%18 iken, Türkiye'de bu oran \%46'dır. Söz konusu durum kadınlara yüklenen geleneksel toplumsal cinsiyete dayalı rollerden kaynaklanmaktadır. Kadınların ev işlerinde yer almaları, ayrıca çocukların ve yaşlıların bakımlarını üstlenmeleri, eğitime ve sonrasında işgücü piyasasına katılım oranlarını düşürmektedir (OECD, Society and Glance, 2016).

Ne eğitimde ne de istihdamda olmayan gençlerin aksine hem eğitimde hem de istihdamda yer alan gençlerin durumuna ilişkin olarak istatistikî bir veri bulunmamaktadır. Benzer şekilde "okulu bırakma/ terk etme" ile ilgili bilgiler de oldukça sınırlıdır, ayrıca nedenleri üzerine herhangi bir veri seti bulunmamaktadır. UNDP’nin “Türkiye 2008 İnsani Gelişme Raporu: Türkiye'de Gençlik" çalışmasında, lise veya üniversiteye gitmeyen gençlere bu durumun nedenleri sorulduğunda, \%30'unun bir işe girip para kazanmaları gerektiğini ya da okul harcamalarını ödeyecek ekonomik durumlarının olmadığını ifade ederken,\%50'si ilgi ve isteklerini kaybettiğini, \%11'i ise okula gitmeme nedeni olarak ailesinin engel olduğunu belirtmiştir. Geçimini sağlamak için okulu bırakan genç erkeklerin sayısı, aynı durumda olan genç kızların sayısının iki katından fazladır, ancak aile baskısıyla okulu bırakmak zorunda kalan genç kadınların sayısı, aynı durumdaki erkeklerin yaklaşık olarak dokuz katıdır (2008, s.27-28). Okula gönderilmeyen, sağlık sorunları yaşayan ya da hükümlü kişiler için alternatif eğitim kurumları olan "açık lise" ve "açık öğretim üniversiteleri", ekonomik yetersizliklerden dolayı eğitim 
yaşamını sürdüremeyen gençler için de bir fırsat olarak durmaktadır. Ancak alınan diplomanın piyasa şartlarındaki değeri düşünülünce, gençlerin örgün eğitimin sınırları dâhilinde kalmak istedikleri anlaşılırdır.

Eğitim, kültürel ve ekonomik anlamda bir yatırım sürecidir, aynı zamanda uzun ve masraflıdır. Eğitim sürecinde kalmak isteyen bireyler için ekonomik yetersizlikleri aşma noktasında çeşitli stratejilerin üretilmesi kaçınılmazdır. Şahin ve diğerleri (2009) “Üniversite Öğrencilerinin Sorunları" adlı saha çalışmasına dayalı makalelerinde, yükseköğretim gençliğinin çoğunluğunun yoğun ekonomik sorunlar yaşadıklarını, yaşamlarını sürdürecek miktarda gelire sahip olmadıklarını, zor koşullarda öğrenimlerini sürdürmeye çalıştıklarını ve temel gereksinimlerini dâhi karşılamakta zorlandıklarını belirtmektedir. Öğrencilerin ekonomik yetersizliklerini temel sorun olarak göstermeleri; hem ailelerin çocuklarının ihtiyaçlarını karşılayamadığını hem de yükseköğretimde kredi ve burs sistemlerinin yeterince etkili işletilemediğini ve ihtiyaçlarını karşılamaktan uzak olduğu şeklinde yorumlanabilir.

Günümüzde eğitimin metalaşması/ticarileşmesi kadar eğitim sistemin giderek değeri düşen diplomalar ve yeterlilik sertifikaları satması, eğitimi bir yatırım olarak gören ve sonunda elde edeceği diploma veya sertifikayla iyi bir iş edinmeyi ve borçlarını ödemeyi düşünen gençleri umutsuzluğa sürüklemektedir (Standing, 2015, s.120, 124, 127). Buna karşın ülkemizde sabit/istikrarlı bir ücretle ve istihdam güvencesiyle çalışmak isteyen bireyler için belirleyici etmen "diplomadır." Gülten Kazgan'ın “İstanbul Gençliği: Gençlik Değerleri Araştırması" (2006, s.191-192) adlı derleme çalışmasında, "hayatta başarılı olmayı sağlayan en önemli şey nedir" sorusuna, gençlerin \%50.1'i "eğitim ya da bilgi" yanıtını vermiştir. Diğer bir soruda ise görüşülenlere "toplumda saygın bir yere sahip olmak için neyin önemli olduğu" sorulmuştur. Buna göre \%36,5'i "iyi bir üniversiteden mezun olmak" cevabını vermiştir. Kazgan'ın "Kuştepe Gençliği Araştırması" (2002, s.37-38) adlı derleme eserinde de, gençler arasında eğitimin toplumsal statüyü yükseltmenin tek yolu olduğuna dair bir sonuca ulaşılmıştır. Ayrıca araştırmada "çalışmak yerine okula devam etmeyi ister misiniz" sorusuna katılımciların \%74,1'i "evet isterim" cevabını vermiştir. Dolayısıyla belirli mevkilerde yer almak isteyen ve bu noktada diplomanın belirleyici bir araç olduğunu düşünen gençlerin, eğitim sürecinde kalma stratejisi olarak, tam ya da yarı zamanlı, güvencesiz ve 
düşük ücretli işlerde, geçici/mevsimlik işgücü olarak yer aldıkları görülmektedir. Hem istihdamda hem de eğitimde olan gençler için "istihdam için eğitim" alg1sı, "eğitim için istihdam" problemine dönüşmektedir.

\section{Üniversite gençliğinin yoksulluk göstergeleri}

Yoksulluk tanımlanması zor bir kavramdır. Sağlık hizmetlerinden yararlanma, eğitime erişim imkânları, iletişim olanaklarının kullanımı, temiz içme suyu sahipliği gibi temel insani ihtiyaçları elde etmek için gerekli olan mallara, hizmetlere ve altyapılara erişim noktasında karşılaşılan yetersizlikler, güçsüzlükler, çaresizlikler yoksulluğun bir göstergesi olduğu gibi aynı zamanda okuryazarlık oranı, yetersiz beslenme düzeyi, düşük yaşam beklentisi, önlenebilir hastalık prevalansı gibi durumlar da yoksulluk kapsamında ele alınan diğer değişkenlerdir. Bireyin kendini gerçekleştirme potansiyelinin önündeki her türden kısıtlama ile sosyal ve hukuki olarak devlet koruma mekanizmalarının olmaması veya yararlanamama durumu da yoksulluğun en geniş tanımı olarak karşımıza çıkmaktadır (Curtain, 20004, s.3,4).

1990 yılında dünya nüfusunun \%37,1'i; 2012 yılında \%12,7'si; 2015 yılında ise \%9,6'sı yoksulluk sınırı olan günlük 1.90 doların altında yaşadığı tahmin edilmektedir. İstatistikler yoksulluk riskinin genç nüfusta daha yüksek olduğunu ortaya koymaktadır. Buna göre yaklaşık 238 milyon gencin günde 1 doların altında aşırı yoksulluk içinde yaşadığı, 462 milyon gencin ise günde 2 doların altında hayatta kalma mücadelesi verdiği görülmektedir (World Bank, 2016, s.4). Türkiye nüfusunun \%14,7'si yoksulluk sınırının altında yaşamaktadır. Finansal sıkıntıda olma durumunu ifade eden maddi yoksunluk oranı ise \%30,3'tür. 15-29 yaş grubu genç erkeklerde yoksulluk sınırı \%22,3; kadınlarda ise \%24,6'dır (TÜIK, 2015). Türkiye'deki yoksulların genel karakteristikleri konusunda şu bulgular tespit edilmiştir: kalabalık hanelerde yaşama, eğitim seviyesinin düşük olması, bölgesel eşitsizlik (en yoksul bölgeler Doğu Anadolu ve Güneydoğu Anadolu), kırsal alanlarda yaşayanların ve özel sektörde çalışanların yoksulluk risklerinin yüksek olması (İzdeş, 2010, s.231).

Türkiye'de yaşayan her beş gençten biri yoksulluk sınırının altında yaşamaktadır. Medyanın kamuoyunu sunduğu bekâr, sağlıklı, dinamik 
ve genelde orta sınıf bireyleri temsil eden "gençlik imajı" nın aksine 15-24 yaş grubunun yalnızca üçte biri öğrenci; kimileri iş arıyor, kimileri ise iş bulma ümidini kaybetmiş durumda; kimileri ebeveynleri ile birlikte yaşarken, kimileri ise evli ve çocukludur. Ayrıca kayıt dışı çalışanların sayısı da oldukça fazladır. Türkiye' de "görünmeyen gençlik" olarak ifade edilen milyonlarca kişi vardır. Bunlar ne eğitimde ne de istihdamda yer alan kadınlar, fiziksel engelliler, iş aramaktan vazgeçmiş gençler, hükümlüler, sokakta yaşayan gençlerden vb. oluşmaktadır (UNDP, 2008, s.13).

Yoksulluk, kuşaklar boyunca uzanan bir gerçekliğe sahiptir. Diploma ise mevcut yoksulluk zincirinin kırılmasında etkili bir araçtır. Eğitim politikaları ile üretilen, yoksul öğrencilerin eğitime erişimi ve eğitim sürecinde kalma problemleri ile ilgili çözümler (burs ve krediler, yurtlar ile kısmi zamanlı çalışma imkânı gibi) aynı zamanda yoksullukla mücadele stratejisi olarak da ele alınabilir. Yoksul gençler üzerine yapılan çalışmalar göstermektedir ki, sosyal dışlanma ve ayrımcllık gibi koşullar altında kendini gerçekleştirme çabasına girişen yoksul öğrenciler, aynı zamanda eğitim yaşamını sürdürebilmek, ailesinin geçim mücadelesine destek verebilmek amacıyla, üniversite eğitimi boyunca çeşitli formel/enformel sektörlere işgücü olarak yer almaktadır.

Konunun diğer bir boyutu ise tüketim kültürü ile ilgilidir. Yoksul öğrenci olmak bu bireylerin "genç olamayanlar" olarak nitelendirilmesini mümkün kılmaktadır. Söz konusu "genç olamayanlar", sosyoekonomik düzeylerinin düşük olmasından dolayı oldukça sınırlı bir evren içinde yaşamaktadır. Ayrıca kurumsal ilişkiler, faaliyet modelleri ve çeşitli fırsat yapıları açısından dezavantajlı oldukları için genel olarak geçim, işsizlik ve güvenlik gibi konularda endişeleri bulunmaktadır (Boratav, 2005, s.205). Demet Lüküslü, “Türkiye'de Gençlik Miti: 1980 Sonrası Türkiye Gençliği" (2009, s.169) adlı çalışmasında, gençlerin çalışmak zorunda kalmalarının ve okula devam edememelerinin en önemli sebebi olarak "parasızlığı" ifade ettiklerini belirtmektedir. Lüküslü'ye göre kamusal olarak gençlere yönelik sosyal, kültürel ve sportif aktivitelerin olmaması ve bu alanların ücretli olması nedeniyle gençlerde, "parayla saadet oluyor" düşüncesi güçlenmektedir. Bu nedenle "tüketim imkânlarına ulaşamayan, 'genç gibi' yaşamayan yoksul gençler kendilerini 'genç olmayan- 
lar' kategorisine dâhil etmektedirler." (Yamanoğlu, 2010, s.56). Yetişkinliğe erken bir geçiş yaparak, ailesi için ya da kendi yaşamsal varlığını sürdürmek için çalışmak zorunda kalanlarla ya da evlenip kendi ailelerini kuran genç bireyler de "genç olamama" durumunun diğer aktörleridir (Uyan-Semerci, 2008, s.415). Buna göre sadece eğitim yaşamını sürdürebilmek ya da ailesinin geçim mücadelesine destek verebilmek amacıyla değil, aynı zamanda tüketim toplumuna dâhil olabilmek için de istihdama katılan öğrenciler bulunmaktadır.

\section{Formel/enformel işgücü olarak üniversite gençliği}

“Gençlere yönelik temel toplumsal beklenti eğitim sisteminde kalmaları ve/veya çalışma hayatına dâhil olmalarıdır. Ancak hangi gençlerin eğitim sisteminde kalacağı, hangi gençlerin çalışma hayatına dâhil olacağ gençlerin sosyal sınıf pozisyonu tarafından belirlenmektedir" (Çelik, 2013, s.41). Weberyan bir kavramla destekleyerek "yaşam şansı" faktörünün de eğitim ve istihdam ilişkilerini etkilediğini ifade edebiliriz. Diğer bir ifadeyle ailenin sahip olduğu "kültürel ve ekonomik sermayenin hacmi ve kompozisyonuna" bağlı olarak değişen eğitim süreci ve istihdam ilişkileri benzer şekilde "yaşam şansı" faktörüne bağlı olarak da (erkek ya da kadın olmak, kentte ya da kırda yaşamak, sağlıklı olmak gibi çok çeşitli faktörlere bağlı olarak) farklılık göstermektedir.

Eğitim sürecinde ya da mezuniyet sonrası işgücü piyasasında genç olmak kolay değildir. 15-24 yaş arasındaki gençler, küresel nüfusun \%18'ini (1.1 milyar kişi) oluşturmaktadır. Öte yandan 2014 yılı verilerine göre dünyadaki işsizlerin \%36,7'si de genç nüfustur. 2007-2010 yılları arasındaki hızlı artış sonrası, küresel gençlik işsizlik oranı, 2012-2014 döneminde \%13'e kadar gerilemiştir (ILO, 2015, s.1). Okuldan işe geçiş, çoğu genç açısından ilk iş için uzun sürmemekle birlikte, istikrarlı veya tatminkâr bir işe geçişin tamamlanması ortalama 19 ay sürmektedir (ILO, 2015, s.3). Türkiye'de ise 15-24 yaş grubundaki genç nüfusun genel nüfusa oranı \%16,3'tür (12 milyon 989 bin) (TÜIK, 2016). İşsizlik oranı bir önceki yıla göre (2016) 3,8 puanlık artış göstererek \%19,8 olmuştur (TUİK, 2017). Görüldüğü üzere Türkiye'deki genç işsizliği küresel genç işsizliği ortalamasının üzerindedir. Gençlerin işgücü durumları ile ilgili diğer bilgiler şu şekildedir: 
- 2016 yılında, Türkiye' de 15-24 yaş grubundaki gençlerin istihdam oranı $\% 34,1^{\prime}$ dir. İstihdam edilen gençlerin $\% 17,6$ 's 1 tarım, \%31,3'ü sanayi, \%51,1'i ise hizmet sektöründe yer almaktadır (TÜİK, 2016).

- Hane halkı işgücü araştırması sonuçlarına göre ne eğitimde ne istihdamda olan gençlerin oranı 2016 yılında \%24'e yükselmiştir (TÜİK, 2016).

- Genç nüfustaki kayıt dışı istihdam oranı ise \%33'tür (TÜİK, 2015).

- İşgücündeki gençlerin \%47,6'sının eğitimi süresince çalışma deneyimi yaşadığı görülmektedir. İşgücüne dâhil olmayan bireylerin ise $\% 19,7^{\prime}$ si eğitimi sırasında bir çalışma deneyimi yaşamamıştır (TÜİK, 2015).

- Gençlerin \%23,3'ü ise ilk işinde hizmet ve satış elemanı olarak çalışmıştır (TÜİK, 2015).

Küresel ölçekte olduğu gibi Türkiye'nin işgücü piyasasının temel problemlerinden biri kayıt dışı istihdamdır. Gençlerin kayıt dışı istihdam oranı yetişkinlere göre daha yüksektir. "İşgücü piyasasına yeni giren gençler, yetişkinlerden daha az vasfa ve daha az deneyime sahiptir. Bu nedenle gençler, çoğunlukla işgücü piyasasında güvencesiz ve düşük ücretli işlerin olduğu ikincil piyasada çalışmaktadır." (Çetinkaya, 2008, s.123).

Yasal olarak tanınan ve/veya yasal düzenlemelerin dışında kalan; küçük ölçekli üreticileri, hizmet verenleri, kendi hesabına çalışanları/serbest meslek sahibi olanları, gündelikçileri ifade etmekle birlikte bunların büyük bir kısmını da kırsal alanlardan gelen kadın ve göçmen gruplar oluşturmaktadır. Diğer yandan gecekondulaşma yerleşimlerine ve şehir sokaklarına dayanan bu sektörler, örgün eğitim sisteminin dışında kazanılan becerileri ve çoğunlukla yerel teknolojileri kullanmakta, aile ve akrabalık ağlarıyla istihdam ilişkilerinin sınırlarını çizmektedir. Büyük ölçüde devlet tarafından tanınmayan bu sektörler, düzenleyici mekanizmalardan kaçınmakta, sendikal kayıtları bulunmamakta, sağlık ve güvenlik gibi konularda da formel bir yapı geliştirmemektedirler. Yapısal uyum programları ve dünya ticaretindeki eşitsizlikler, ayrıca kamu sektörünün ve özel sektör emeğinin giderek daralması, bu türden sektörlerde çalışan birey sayısını her geçen gün artırmaktadır (Birchall, 2001, s.14). 
Söz konusu yeni istihdam biçimleri "eğreti istihdam" olarak tanımlanmaktadır (Temiz, 2004, s.56).“Eğreti istihdamın bir diğer gerekçesi de yoksulluktur. Yoksulluk, bireylerin formel işgücü piyasasına katılmalarını engellemekte ve onları enformel sektörlere yönlendirmektedir" (Temiz, 2004, s.66). Fatih Kahraman ve Burak Kahraman'ın (2016) "Mevsimlik İstihdamın Eğitimli Gençleri: İnşaatlarda Çalışan Üniversite Öğrencileri Üzerine Bir Araştırma" adlı çalışmalarında, Nevşehir Hacı Bektaş Veli Üniversitesinde eğitimlerine devam eden yükseköğretim öğrencilerinin inşaat sektöründe çalışma nedenleri incelenmiştir. Çalışma sonucunda yoksul öğrencilerin, eğitim yaşamlarını sürdürebilmek için çalışmak zorunda kaldıkları saptanmıştır.

Neoliberal görüş, işgücü piyasasında esneklik politikalarının izlenmesinin yatırım ve istihdamın sürdürebilmesi için zorunlu olduğunu ifade etmektedir $\mathrm{ki}$, bu durum istihdam güvenliğinin azalmasına ve ücretlerin düşmesine neden olmaktadır. Guy Standing, güvencesiz (precarious) ve proletarya (plotetariat) kelimelerinin birleştirilmesiyle türetilen "prekarya" kavramına atıfta bulunarak, gençlerin küreselleşen işgücü piyasalarındaki güvencesiz ve düşük ücretli konumlarına işaret etmektedir. Uzun dönemli, istikrarlı, sabit-zamanlı çalışan, ne kadar ve nasıl ilerleyeceğini bilen, sendikal güvenceye sahip olan proletaryadan farklı olarak prekaryanın emeği araçsal (yaşamak için), fırsatçı (ne düşerse) ve güvencesizdir (2015, s.19-21, 31, 119). Üniversite gençliği de prekaryanın bir parçasıdır. Diğerleri gibi düşük ücretlerle ve güvencesiz çalışmaktadır, ancak sadece yaşamak için değil aynı zamanda iyi bir geleceğe sahip olmak için de firsatları değerlendirmektedir.

\section{Araştırmanın metodolojisi}

Tarım, imalat, inşaat, turizm gibi emek-yoğun sektörlerde; güvencesiz, düşük ücretli, geçici/mevsimlik işgücü olarak formel/enformel bir şekilde istihdam edilen üniversite öğrencileri araştırmanın evrenini oluşturmaktadır. Bu kapsamda Akdeniz Üniversitesi'nde öğrenci olan ve söz konusu sektörlerde çalışmakta olan 22 kişiyle görüşmeler gerçekleştirilmiştir. Araştırmacının öğretim üyesi, görüşülen kişilerin de öğrenci olması nedeniyle ortaya çıkabilecek "sembolik şiddetin" azaltılmasına yönelik 
olarak çalışmada, Bourdieu'nun "aktif ve metodik dinleme" tekniği kullanılmıştır. Bu tekniğin amacı, araştırmacı ile görüşülen kişi arasındaki toplumsal hiyerarşinin, yani kişinin sahip olduğu sermaye türlerinin ortaya çıkarmış olduğu toplumsal asimetrileri telafi etmek, ayrıca görüşme esnasında kurulan dilsel ve sembolik etkileşimin yönlendirici olmadan gerçekleşmesini sağlamaktır. Böylelikle araştırmacı, görüşülen kişinin dilini, görüşlerini, duygularını ve düşüncelerini kontrollü bir şekilde taklit ederek, kendine yönelik düşünümsellik (reflexivity) görevini yerine getirir (1999, s.608, 609). Araştırmacı ile görüşülen kişi arasındaki mesafenin daraltılması için görüşmeler, Akdeniz Üniversitesi içinde bulunan "Yakut", "Olbia" ve "Ceypark" çarşılarında gerçekleştirilmiştir. Ayrıca görüşmeler esnasında "yaşam anlatısı" tekniğinden de yararlanılarak, görüşülen bireyle, somut olaylar ve olgular üzerinden yakınlık kurulmaya çalışılmış ve probleminin taşıyıcısı olan bireylerin yaşam süreçleri ile ilgili ayrıntılara yer verilmiştir. Elde edilen veriler, içerik analizi yöntemiyle çözümlenmiştir.

\section{Araştırmanın bulguları}

Hem istihdamda hem de eğitimde olan öğrencilerin; sosyo-demografik özellikleri, hane bilgileri, istihdam alanları ve koşulları ile ilgili olarak genel bir değerlendirme yapabilmek, söz konusu durumların, Türkiye' deki eğitime erişim (eşitsizlik) hususundaki genel problemlerle benzerlik gösterip-göstermediğini karşılaştırabilmek amacıyla, elde edilen veriler tablolar halinde özetlenmiştir.

\section{Öğrencilerin sosyo-demografik özellikleri}

Örneklem grubumuz, 19-24 yaş aralığında değişen, 10 kadın ve 12 erkek öğrenciden oluşmaktadır. Katılımcıların, Türkiye'nin çeşitli coğrafi bölgelerinden, ağırlıklı olarak da Doğu ve Güneydoğu Anadolu Bölgesi'nden geldikleri görülmektedir. Kayıt dışı sektör büyüklügünün ve işsizlik oranlarının yüksek olduğu, istihdam ve işgücüne katılım oranlarının düşük olduğu bu bölgeler, aynı zamanda eğitime erişim, yoksulluk, fırsat eşitliği, toplumsal cinsiyet eşitsizliği gibi değişkenler açısından da dezavantajlı yerleşim yerleridir. Dolayısıyla örneklem grubumuzun, genel itibariyle bölgesel eşitsizliklerin yoğun olduğu illerden gelen öğrencilerden 
oluşması anlaşılırdır. Diğer yandan katılımcların, istihdam alanlarının kısıtlı olduğu bölümlerde eğitim aldıkları görülmektedir. Sosyoloji, Felsefe, Tarih, Kamu Yönetimi, İktisat, Uluslararası İlişkiler, Su Ürünleri Mühendisliği ve Bilgisayar Programcıllğı bölümleri, Türkiye'deki üniversitelerin hemen hemen hepsinde olan ve oldukça fazla mezun veren alanlardır. Bu durum öğrencileri, alternatif istihdam alanlarına, diğer bir deyişle eğitim aldıkları alanlardan farklı iş sahalarında tecrübe kazanmaya yöneltmektedir.

Tablo 1. Görüşülenlerin Sosyo-Demografik Özellikleri

Kod-Cinsiyet- Yaş- Doğum Yeri- Bölüm- Kaldığı Yer- Destek/Burs- Aylık Geliri

G1- Erkek-21-Muş/Arpayazı- Hukuk-Ev-Öğrenim Kredisi-900 TL

G2- Kadın-21- Diyarbakır/Merkez- İktisat-Ev-Öğrenim Kredisi-1200 TL

G3- Kadın- 22- Batman/Beşiri-Hemşirelik-Ev- Öğrenim. Kredisi-900 TL

G4-Kadın-23-Konya/Selçuklu-Bilgisayar Programcılığı-Ev-Yok-900 TL

G5-Kadın-24-Antalya/Alanya-Uluslararası İlişkiler-Ev- Öğrenim Kredisi-430 TL

G6-Erkek-22-Sivas/Zara-Felsefe-Ev-Devlet Bursu-750 TL

G7-Erkek-24-Van/Erciş-Su Ürünleri Mühendisliği-Ev-Yok-1000 TL

G8-Erkek-21-Uşak/Banaz-Türkçe Öğretmenliği-Ev-Yok-650-700 TL

G9-Kadın-23-Uşak/Banaz-Sosyoloji-Devlet Yurdu-Devlet Bursu-500 TL

G10-Erkek-21-Samsun/Vezirköprü-Sosyoloji-Özel Yurt-Devlet Bursu-700-800 TL

G11-Erkek-22-Karaman/Merkez-Diş Hekimliği-Ev-Öğrenim Kredisi-700-800 TL

G12-Erkek-20-Mersin/Mut-Ekonometri-Devlet Yurdu-Devlet Bursu-500 TL

G13-Erkek-24-Aydın/İncirliova-Kamu Yönetimi-D. Yurdu-Ö. Kredisi-500 TL

G14-Kadın-21-Konya/Ereğli-Hemşirelik-Ev (Annesiyle birlikte)-Ö. Kredisi-475 TL

G15-Kadın-23-Muğla/Dalaman-i̇ktisat-Devlet Yurdu-Devlet Bursu-400-500 TL

G16-Kadın-23-Ordu/Altınordu-Gerontoloji-Devlet Yurdu-Devlet Bursu-650 TL

G17-Erkek-21-Şanlıurfa/Merkez-Felsefe-Ev-Yok-400-450 TL

G18-Kadın-19-Van-Bilgisayar Programcılığı-D. Yurdu-Öğrenim Kredisi-425 TL

G19-Kadın-23-Van/Çaldıran-Felsefe-Devlet Yurdu-Devlet Bursu-425 TL

G20-Erkek-23-Manisa/Alaşehir-Tarih-Devlet Yurdu-Yok-700-750 TL

G21-Erkek-22-Muğla/Bodrum-Fen Bilgisi Öğretmenliği-Ev-Yok-1200 TL

G22-Erkek-24-Şırnak/İdil-Felsefe-Ev-Öğrenim Kredisi, Burs-1000 TL

Tablo-1'de görüldüğü üzere öğrencilerin bir kısmı sadece öğrenim kredisi ya da devlet bursu ile geçimlerini sağlamaktadır. Söz konusu gençler aynı zamanda devlet yurdunda kalmaktadır. Maddi durumu biraz daha iyi olan ya da yıl boyunca çalışan öğrencilerse barınma yeri olarak evi tercih etmektedirler. 


\section{Öğrencilerin hanelerine ilişkin göstergeler}

Eğitime erişimi ve eğitim sürecinde kalmayı etkileyen faktörlerin başında, ekonomik yetersizlikler gelmektedir. Yoksulluklara eşlik eden farklı türden değişkenlerin de varlığı, öğrencileri çeşitli stratejiler üretmeye sevk etmektedir. Ebeveynlerin bir arada yaşayıp yaşamadığından, sağ olup olmamalarına, ebeveynlerin eğitim ve meslek durumlarından, hane gelirine, çocuk sayısına vb. kadar birçok değişken, bireyin eğitim sürecinde kalma stratejilerini farklılaştırmaktadır.

Tablo 2. Görüşülenlerin Hanelerine İlişkin Göstergeler

Kod-Anne/Baba Eğitim- Anne/Baba Meslek-Çocuk Sayısı-Hane Gelir- Güvence-Konut G1-Okur-yazar/İlkokul- Ev hanımı/Emekli-13 çocuk-1700 TL-Bağkur-Ev Sahibi G2-Lise terk/ilkokul terk- Ev hanımı/Emekli (Ek iş yapıyor)-5 çocuk -4000 TL-Bağkur-Kira

G3-İlkokul/Ilkokul- Ev Hanımı/Serbest Meslek-5 çocuk-5000 TL-SGK-Ev Sahibi

G4-İlkokul/i̇lkokul-Ev Hanımı/Emekli-8 çocuk-2000 TL-SGK-Kira

G5-İlkokul/Ortaokul-Ev Hanımı/Aşç1-3 çocuk-1400 TL-SGK-Kira

G6- İlkokul terk/İlkokul terk-Ev Hanımı/İnşaat İşçisi-4 çocuk-3000 TL-SGK-Kira

G7-Okur-yazar değil/ İlkokul- Ev Hanımı/ Emekli-7 çocuk-1100 TL-Bağkur-Ev Sahibi

G8-illkokul/ İlkokul- Ev Hanımı/Serbest Meslek-1 çocuk-1500 TL-Bağkur-Kira

G9- İlkokul/Ortaokul- Ev Hanımı/İşsiz (6 yıldır)-3 çocuk-1000 TL-Bağkur-Kira G10-Ortaokul/Ortaokul- Ev Hanımı/İnşaat İşçisi-3 çocuk-2000 TL-SSK-Ev Sahibi

G11-İlkoku1/Lise- Ev Hanımı/Esnaf-3 çocuk-2000 TL-Bağkur-Ev Sahibi

G12-Lise/Lise- Halk Eğitim'de Usta Öğretici/Emekli-2 çocuk-2000 TL-SGK-Ev Sahibi

G13-Okur-yazar değil- Ev Hanımı/İnşaat İşçisi-8 çocuk-2400 TL-SGK-Ev Sahibi

G14- Ortaokul/Lise- İşçi (otelde)/ İşçi (petrol ofisinde)-1 çocuk-1600 TL-SGK-Kira

G15-Ortaokul/Ortaokul- Ev Hanımı/Emekli-3 çocuk-1400 TL-SGK-Kira Ödemiyor

G16- Lise/Lise- Ev hanımı/Emekli (Ek iş)-2 çocuk-3000 TL-SGK-Ev Sahibi

G17- Okur-yazar değil/IIlkokul- Ev han./Emekli (Ek iş)-10 çocuk-1200 TL-Bağkur-Ev Sahibi

G18-ïlkokul/İlkokul- Ev hanımı/Çiftçi-5 çocuk-1500 TL-SGK-Kira

G19-ïlkokul terk/İlkokul terk-Ev hanımı/Serbest Meslek-8 çocuk-1500 TL-Yeşil Kart-Kira

G20- İlkokul/Lise- Ev hanımı/Memur-2 çocuk-1500 TL-SGK-Ev Sahibi

G21- İlkokul/İlkokul- Ev hanımı/Aşçı Başı-2 çocuk-5000 TL-SGK-Ev Sahibi

G22- Okur-yazar değil/İlkokul- Ev hanımı/İnşaat İş.-11 çocuk-4000 TL-Yeşil Kart-Ev Sahibi

Tablo-2 genel olarak değerlendirildiğinde; kalabalık hanelerde yaşama, ebeveynlerin eğitim seviyesinin düşük olması, hane gelir yetersizliği gibi Türkiye'de eğitime erişimi etkileyen faktörlerin, örneklem grubumuz açısından da benzer olduğu görülmektedir. Bölgesel eşitsizli- 
klerin yanı sıra anne ve babanın ayrı yaşaması $(G 14, G 20)$ ya da ebeveynlerden birinin kaybı (G6, G8) gibi değişkenlerde öğrencileri, hem istihdamda hem eğitimde var olmaya zorlamaktadır:

"Anne baba ayrı bir çocuk olduğum için birazck daha sorumluluk bana yükleniyor, işte faturalarm ödenmesi, evde bir şeyler alınacaksa. Hani birazcık daha olgunum bir ev geçindirme konusunda, bilgiliyim diye düşünüyorum." (G14, Kadın, Hemşirelik).

"Ailede kişi sayısı fazla, babam geçimimizi sağlamakta zorlanıyor, bu yüzden evin ekonomisine destek olmak gerek. Mesela abim yüksek lisans eğitimini yarrm biraktı, polis oldu." (G17, Erkek, Felsefe).

\section{Yükseköğretim öğrencilerin istihdam alanları ve koşulları}

Üniversite öğrencilerinin çeşitli istihdam alanlarında, özellikle kayıt-dışı sektörlerde; mevsimlik/geçici, düşük ücretli, uzun çalışma saatleri ve iş güvencesinden yoksun bir şekilde çalıştıkları görülmektedir:

Tablo 3. Görü̈sülenlerin İstihdam Alanları ve Koşulları

\begin{tabular}{|c|c|}
\hline \multicolumn{2}{|r|}{ Sektör-İş Bulma Şekli-Çalışılan Süre-İl-Çalışma Yaşı-Ücret-Sigorta-Çalışma Saati } \\
\hline \multirow[t]{5}{*}{ G1 } & Garson-Arkadaş-2 yıl-Adana-15, 16- Günlük 15-20 TL-Yok- 8-10 Saat \\
\hline & İmalat Fabrikasında İşçi-Arkadaş-1 Hafta-Adana-16-17-Günlük 12 TL-Yok-8 Saat \\
\hline & İnşaat İşçisi-Arkadaş-Ara ara, tatillerde-Adana-17-18-Günlük 40 TL-Yok-8 Saat \\
\hline & Fırın İșçisi-Arkadaş-2 yıl-Adana-13, 14-Günlük 10 TL-Yok-10 Saat \\
\hline & Mal Sayımı-Arkadaş-Ara ara-Antalya-20, 21-Günlük 50 TL-Var-10-12 Saat \\
\hline G2 & Kütüphane-Kendim-2,5 yıl-Antalya-19,20, 21-Aylık 450 TL-Var-4 Saat \\
\hline \multirow[t]{2}{*}{ G3 } & Anketör-Arkadaş-Ara ara-Antalya-21, 22-Anket baş1 6 TL-Yok-Belirsiz \\
\hline & Sekreterlik-3 Hafta-Antalya-22-Günlük 70 TL-Yok-8 Saat \\
\hline \multirow[t]{2}{*}{ G4 } & Market Çalışanı-Kendi-1 yıl-Aydın-17-Aylık 230 TL-Var- 8 saat \\
\hline & Market Çalışanı-Kendi-3 yıl-Antalya-18-23-Aylık 900 TL-Var-8 saat \\
\hline \multirow[t]{3}{*}{ G5 } & Çocuk Tiyatros-Arkadaş-1 yıl-Antalya-19-Günlük 40 TL-Yok-12 Saat \\
\hline & Garson-Arkadaş-1 ay-Antalya-20-Aylık 650 TL-Var-8 Saat \\
\hline & Mağaza Çalışanı-Arkadaş-1 ay-Antalya-21-Aylık 800 TL-Var-11 Saat \\
\hline \multirow[t]{2}{*}{ G6 } & Fabrika İşçisi-Akraba-2 ay-Denizli-17, 18-Günlük 30 TL-Yok-9 saat \\
\hline & Betonarme Ustas1-Akraba-24 gün-İstanbul-22-Günlük100 TL-Var-8 saat + mesai \\
\hline G7 & İnşaat İşçisi-Aile/Akraba-Sürekli-İstanbul-16 yaşından beri- değişmekte-Yok- \\
\hline G8 & Tarım İşçisi-Akraba-6 yıldır-Uşak-15 yaşından beri-Günlük 100 TL-Yok-11 saat \\
\hline \multirow[t]{4}{*}{ G9 } & Tekstil İşçisi-Arkadaş-Akraba-2,5 ay-Uşak-22-Günlük 30 TL-Yok-9 saat \\
\hline & Tarım İşçisi- Akraba-Uşak-11 yaşımdan beri-Günlük 15-40 TL-Yok-12 saat \\
\hline & G1da Sektörü-Arkadaş-Akraba-3 hafta-Uşak-22-Günlük 50 TL-Yok-12 saat \\
\hline & Animatör-Arkadaş-Akraba-6 hafta-Antalya-22-Günlük 60 TL-Yok-7 saat \\
\hline
\end{tabular}




\begin{tabular}{|c|c|}
\hline G10 & İnşaat İşçisi-Akraba-2 ay-Samsun-20 Günlük 65 TL-Yok-11 saat \\
\hline \multirow[t]{2}{*}{ G11 } & Tarım İşçisi-Akraba-7 yıl-Karaman-15 yaşından beri-Günlük 100 TL-Yok-11 saat \\
\hline & Garson-Akraba-2 yıl-Antalya-21, 22-Günlük 50TL-Yok-10 saat \\
\hline \multirow[t]{3}{*}{ G12 } & Kargo Elemanı-Akraba-3 ay-Karaman-18-Günlük 40TL-Yok-8 saat \\
\hline & Garson-Arkadaş-2 ay-Antalya-19-Günlük 30 TL-Yok-8 saat \\
\hline & Animatör-Arkadaş-3 ay-Antalya-20-Günlük 50 TL-Var-3-5 saat \\
\hline \multirow[t]{4}{*}{ G13 } & Turizm Sektörü-Aile-4-5 ay-Bodrum-17, 18-Aylık-900TL-Var-13-14 saat \\
\hline & Animatör-Arkadaş-İş oldukça-Antalya-23-Günlük 50 TL-Var-12 saat \\
\hline & Şarap evi-Arkadaş-Ayda 3-4 kez-Antalya-24-Günlük 75 TL-Yok-10 saat \\
\hline & Çocuk Tiyatrosu-Arkadaş-Ara ara-Antalya-23-Günlük 35-50 TL-Yok-4 saat \\
\hline \multirow[t]{3}{*}{ G14 } & Satış Elamani-Kendim-2 ay-3 ay-Antalya-18, 20-Asgari ücret-Var-8 saat \\
\hline & Ürün Tanıtımı-Arkadaş-Zaman zaman-Antalya-20, 21-Günlük-50 TL-Yok-8 saat \\
\hline & Animatör-Arkadaş- tatillerde-Antalya-20, 21-Günlük 50 TL-Var-5 saat \\
\hline \multirow[t]{4}{*}{ G15 } & Organizasyon-Arkadaş-1 ay, ara ara-Antalya-22-Günlük 50 TL-Yok-7 saat \\
\hline & Stant Görevlisi-Arkadaş-2 hafta-Antalya-23-Günlük 60 TL-Yok-14-15 saat \\
\hline & Ürün Tanıtımı-Arkadaş-Ara ara-Antalya-23-Günlük 50-60 TL-Yok-10-12 saat \\
\hline & Tekne Temizliği-Akraba-1 ay-Muğla-22- Günlük 80 TL-Yok-7-8 saat \\
\hline \multirow[t]{4}{*}{ G16 } & Organizasyon-Arkadaş-Ara ara-Antalya-22-Günlük 50 TL-Yok-4-5 saat \\
\hline & Ürün Tanitımı-Arkadaş-Ara ara-Antalya-22-Günlük-40 TL-Yok-9-14 saat \\
\hline & Matematik Dersi Verme-Arkadaş-3 ay-Antalya-23-Ders baş1 25 TL-Yok-1-2 saat \\
\hline & Mevsimlik işçi (fındık)-Aile-15 gün-Ordu-20, 21, 22-Günlük 65-70 TL-Yok-9 saat \\
\hline \multirow[t]{3}{*}{ G17 } & Tarım işçisi-Aile-Urfa-Çocukluktan beri-Yok \\
\hline & Tersane işçisi-Kendi-3 ay-İstanbul-17-Asgari ücret-Yok-8 saat ve mesai \\
\hline & Turizm-Kendi-Yaz aylarında-Antalya-20, 21-Asgari ücret-Var-10-12 saat \\
\hline G18 & Turizm-Akraba-Yaz aylarında-Antalya-17 yaşından itibaren-Asgari ücret-Var-8 saat \\
\hline \multirow[t]{2}{*}{ G19 } & Turizm-Akraba-Yaz aylarında-Antalya-2 senedir-Asgari ücret-Var-8 saat \\
\hline & Garson-Akraba-Yaz aylarında-Antalya-20- Aylık1000 TL-Yok-8 saat \\
\hline G20 & Turizmin-Kendim-Yaz aylarında-Antalya-18 yaşından beri-Asgari ücret-Var-8 saat \\
\hline G21 & Turizm ve Hizmet-Akraba-Yaz aylarında-Muğla-15 yaşından beri- Var-14 \\
\hline \multirow[t]{3}{*}{ G22 } & Turizm-Akraba-Yazın-Bodrum-18 yaşından beri-1000-1400 TL-Var-10-12 saat \\
\hline & Tarım İşçisi-Akraba-Yaz aylarında-Düzce-16-18-Günlük-Yok-8-9 saat \\
\hline & Garsonluk.-Akraba-Ara ara-Antalya-2-3 senedir-Günlük 45 TL-Yok-7-8 saat \\
\hline
\end{tabular}

Turizm, tarım, inşaat ve hizmet sektörlerindeki işgücü gereksinimin, yarı vasıflı ya da vasıfsız olması, yükseköğretim öğrencilerinin bu alanlarda iş bulabilmesini kolaylaştırmaktadır. TÜİK verilerine göre işgücündeki gençlerin \%47,6'sı eğitimi süresince çalışma deneyimi yaşamıştır. Gençlerin \%23,3'ü ise ilk işinde hizmet ve satış elemanı olarak çalıştıklarını ifade etmiştir (TÜIKK, 2015). Tablo-3'te görüldüğü üzere inşaat, tarım, turizm, tekstil, hizmet gibi çeşitli sektörlerde mevsimlik/geçici, tam ya da kısmi zamanlı olarak çalışan öğrencilerin yanı sıra 
animatör, garsonluk, tanıtım elemanı, satış elemanı gibi günübirlik işlerde de çalışan gençler bulunmaktadır.

"Tekstil sektöründe çalışıyorken, şal katlama ve bu şalların saçaklarım yakmak için yakma makinesi olarak adlandırılan, ağır gaz kokusu olan ve yüksek ısıya sahip bir makine kullanmaktaydım. Bu makineyi iki kişi karşılıkl olarak kullanmakta ve mutlaka insan elini kolunu yakmakta..." (G9, Kadın, Sosyoloji)

"Bir keresinde ayağıma kaynar su döküldü. Bir başkasında ise alkollü bir müşteri olay çıkardl, yaranabilirdim. Sonu karakolda bitti." (G21, Erkek, Fen Bilgisi Öğretmenliği)

"İçki şişeleriyle gösteri yapıyorum derken elimi yaktım." (G22, Erkek, Felsefe)

Yükseköğretim öğrencilerinin emek yoğun formel/enformel sektörlerde istihdam edilmesi, beraberinde bazı riskleri de ortaya çıkarmaktadır. Güvencesiz bir şekilde çalışmanın riskleri kadar, görmüş oldukları "sembolik şiddet" türleri de, öğrencilerin sağlıklarını etkilemektedir:

"Psikolojik olarak yıprandığımı hissediyorum."(G3, Kadın, Hemşirelik)

"Otelde çalıştığım için eşitsizlikleri daha çok fark ettim. Müşteri parayı verince bizi de satın aldığını sanıyor."(G21, Erkek, Fen Bilgisi Öğretmenliği)

Katılımcıların iş bulma süreçlerinde, toplumsal etkileşimde bulundukları ağların, özellikle aile ve akrabalık ilişkilerinin etkili olduğu görülmektedir. Dikkati çeken bir diğer husus, katılımcıların çalışma yaşamına katılma yaşının 11-12'ye kadar düşmesidir. Dolayısıyla yükseköğretim öğrencileri için istihdamda yer almak, hayat boyu süren bir süreçtir ve deneyimlenen bu gerçeklik sayesinde farklı istihdam alanlarına da kolaylıkla geçiş yapabilmektedirler. Örneğin örneklem grubumuzdaki bazı öğrenciler çalışmaya başladıktan sonra özgüvenlerinin yükseldiğini ifade etmiştir: “Özgüven eksikliği yaşıyordum, çalışmamla bunu aştım"(G3, Kadın, Hemşirelik). Benzer şekilde bazı öğrenciler ise çalışma yaşamının kendisine sorumluluk duygusunu aşıladığını ifade etmiştir:

"Çalışıyor olmam, bana sorumluluk alma, ayaklarımın üzerinde durmamı ögrretti."(G6, Erkek, Felsefe)

"Daha önce evin bütün ihtiyaçlarm, alışverişini ailem yapardl. Onun için hiçbir şeyin fiyatına gidip bakmazdım. Eve çıktıktan ve çalışmaya başladıktan sonra her şeye dikkat ediyorsunuz, fiyatları karşılaştırıyorsunuz, en uygununu bulmaya çalışıyorsunuz."(G2, Kadın, İktisat). 


\section{Yükseköğretim öğrencilerin istihdamda olma sebepleri}

Yükseköğretim öğrencileri ile gerçekleştirilen görüşmeler sonucunda, öğrencilerin formel/enformel istihdamda yer alma sebeplerinin dört başlık etrafında toplandığı saptanmıştır:

-Ĕ̆itim yaşamını devam ettirme stratejisi: Yükseköğretim öğrencisi için eğitim sürecine dâhil olabilmek kadar, bu eğitimi tamamlamakta bir meseledir. Ekonomik olarak yetersizlikler yaşayan öğrenciler ise söz konusu süreci telafi edici stratejiler üreterek, eğitimde kalmayı sağlamaya çalışmaktadırlar. Tablo-3'te görüldüğü üzere öğrenciler çeşitli formel/enformel sektörlerde çalışmaktadırlar. Hatta birçoğu birden fazla alanda iş deneyimine sahiptir.

"Okula devam etmek için farklı yerlerde çalışıyorum." (G8, Erkek, Türkçe Öğretmenliği)

"Yazın çalışmasaydım, formasyon ücretini ödeyemezdim." (G 6, Erkek, Felsefe)

"YDS sinavina, uzmanlık sinavina param olmadığı için giremedim. Çalışmazsam, olmuyor." (G11, Erkek, Diş Hekimliği)

Okumak için çalışmak zorunda olan öğrenciler, aynı zamanda çeşitli tasarruf stratejileri geliştirerek, eğitim sürecinde karşılaştıkları bir takım problemleri telafi etmektedirler:

"Kitaplar yeri geldiği zaman alamıyoruz, cebimizde yeterli para olmuyor. Gerekli olan kitapları alıyoruz ya da fotokopisini alyyoruz" (G1, Erkek, Hukuk)

"Kitaplar pahalı olduğu için fotokopilerini almaya çalışıyorum veya arkadaşlarımla ortak kullanıyorum." (G9, Kadın, Sosyoloji)

Yükseköğretim öğrencileri açısından, eğitimi sürdürebilmede, birikim stratejisi de kullanılmaktadır. Karınca misali yazı çalışarak geçirmek nasıl kışı rahat çıkarmayı sağlarsa, benzer şekilde yükseköğretim öğrencileri de yaz aylarında çalışarak, birikim yapmakta ve bu birikimlerini başta eğitim olmak üzere çeşitli ihtiyaçlarını gidermede kullanmaktadırlar:

"Kazanmış olduğum para ile çeşitli ihtiyaçlarımı karşılıyorum. Zaten kazanılan paranın devamı olmadığından önce birikim yaptım. Bu parayı eğitim masraflarım için harcamayı düşünüyorum. Üniversiten sonra KPSS kitapları vs. için. Şu an yüksek lisansı kazandığım için kazandı̆̆ım parayı dil eğitimim için kullanıyorum." (G9, Kadın, Sosyoloji) 
"Kazandığım parayı okula harcıyorum. Sürekli kazanıyor gibi görünüyorum ama öyle değil. Malzeme almak için birikim yapıyorum." (G11, Erkek, Diş Hekimliği)

"İşte KPSS'ye gireceksem, onun parasını yatırayım diye çalıştım. Zaten hafta sonu 2 gün çalışınca 100 lira alıyordum."(G14, Kadın, Sosyoloji)

"Parayı biriktirmeye çalışıyorum. Biriktirdiğim parayla formasyon alıyorum. Akademik kariyer yapmak istiyorum. Bunun için de gelecek yılda çalışarak kurslara gitmeyi planliyorum." (G17, Erkek, Felsefe)

-Mutlak ve/veya göreli yoksulluklarnyla mücadele etme stratejisi: Örneklem grubumuzda yer alan öğrencilerin kalabalık hanelerde yaşaması, anne-baba eğitim durumlarının düşük olması, anne ya da babanın vefat etmesi ya da ayrı yaşaması, kiracı olmaları ve genel olarak hane gelir seviyesinin düşük olması gibi göstergelerden hareket ederek, mutlak ve/veya göreli yoksulluk içinde olduklarını ifade edebiliriz. Eğitime erişim ve sürdürebilirlik açısından maddi destek alamayan öğrenciler içinde çalışmak bir zorunluluktur:

"Ekonomik durumumu biraz daha geliştirmek için çalışıyorum. Onun dışında ailemi de desteklemek için. Kardeşim zaten üniversiteye gidecekti. Müzik öğretmenliği istiyordu olmadı. Hani onun için biraz daha çalıştım. Para gitsin. Çünkü aileme yük olmayayım... Hani kendime de harcama yapıyorum, giyimime kuşamıma elbette ki, onlar da var." (G 12, Erkek, Ekonometri)

"Aileme yük olmamak için, kendimi ikame edebilmek için çalışıyorum. Belli bir yaştan sonra para isteme sıkıntılı oluyor."(G 13, Erkek, Kamu Yönetimi)

"Boş zamanlarımda zaten bir şeyler yapıyordum. Ben daha çok aileme yük olmamak için, annemle yaşadığım için. Hani o zaten evin kirası faturalar falan ödediği için ona çok yük olmayayım diye öyle çalıştım. Sağlıkla ilgili kitaplar almıştım. Onların taksitlerini ödemek için çalışıyordum..." (G14, Kadın, Hemşirelik)

"Ĕğitim hayatımı sürdürmek ve aileme yük olmamak için çalışıyorum. İmkânım olduğu takdirde bu parayı boş zaman aktiviteleri için de kullanıyorum."(G9, Kadın, Sosyoloji)

Ailenin sahip olduğu ekonomik ve kültürel sermayesinin hacmi ve kompozisyonu kadar, mekânsal koşullarda (kırsal-kentsel, Doğu ve Güneydoğu Anadolu Bölgesi) öğrencilerin eğitim sürecini etkilemektedir. Yoksul öğrenciler için istihdama katılmak, eğitim sürecini devam ettire- 
bilmenin bir yoludur. Söz konusu strateji, yükseköğretim öğrencilerini enformel sektörlere yönlendirmekte, güvencesiz yaşamları ortaya çıkarmakta ve formel/enformel sektörlerde düşük ücretli çalışmaya zorlamaktadır.

-Tüketim alanın içinde olma ve sosyal dışlanmaya maruz kalmama stratejisi: Modern "tüketim, sembolik anlam sistemleri üzerine kuruludur" (Bocock, 2009: 56). Kişinin statüsüne, sosyal değerlerine, kültürel özelliklerine, aidiyet duygusuna paralel olarak sosyal dünyasını inşa etmesi ve buna göre diğer insanlarla iletişim kurması, tüketim davranışıyla mümkün hâle gelir. Yani satın alma/alabilme ya da almama/alamama sadece malların ve hizmetlerin arasından bir tercih değil, aynı zamanda yaşam tarzı inşa etme, sergileme ve ötekileriyle paylaşma veya dışlama amacıyla gerçekleştirilmektedir (Zorlu, 2006: 90). Nihayetinde öğrenciler açısından da, istihdamda yer almak; tüketim sürecine dâhil olabilmeyi ve sosyal etkileşimde bulunmayı mümkün hâle getirmektedir. Bir diğer deyişle çalışan gençler, eğitim sürecinde kalmayı istemektedirler, ancak çalışmayanlara göre mali açlardan ya da sosyal çevrenin genişlemesi açısından bazı kazanımlarının olduğunun da farkındadırlar (Kazgan, 2002: 38).

"Üniversite ortamına ayak uydurmak için de çalışmak zorunda hissediyorum, sadece eğitim masraflarımı karşılamak için değil." (G20, Erkek, Tarih)

"Geziyorum, alışveriş yapıyorum. Zaruri olmayan ihtiyaçlarımı karşıllyorum. Temel ihtiyaçlarımı ailem karşılıyor, onun dışında kalan isteklerimi kendim ne kadar çok kazanırsam o kadar rahat karşılayabiliyorum." (G16, Kadın, Gerontoloji)

“Şimdi lisedeyken forma giyiyorduk. Öyle dışarı çıktığımız zamanda üzerimize başımıza çok dikkat etmiyorduk açıkçası... Ama üniversiteye geldiğin zaman her zaman bir sivil kryafetlesin. Ve ister istemez şu insanda oluyor, ulan acaba kıyafetim düzgün mü? Ve şöyle bir şey de var, insan kendini güzel giydirdiği zaman bir özgüven geliyor insana."(G12, Erkek, Ekonometri)

"Genç olma hali", tüketim dünyasına girmeyi zorunlu kılmaktadır. Gençlik profili açısından değerlendirildiğinde, yükseköğretim gençliğinin oldukça renkli ve çeşitli olduğu söylenebilir. Sosyal, kültürel ve ekonomik farklılıklara sahip olan, aynı zamanda farklı bölgelerden gelen öğrencilerin, aynı mekânı paylaşmaları ve karşılaşmaları beraberinde yaşam tarzı ve beğeni kalıpları üzerinden de, birliktelikleri veya dışlanmaları ortaya 
çıkarmaktadır. Öte yandan üniversite gençliği kendi varlığını boş zaman faaliyetleri üzerinden de kurgulamaktadır. Dolayısıyla istihdama katılmak aynı zamanda boş zaman faaliyetlerinde de yer almayı mümkün kılmaktadır:

"Çalışıyorum ama aşırı bir ekonomik yetersizliklerden dolayı değil. Sadece daha iyi imkânlarda yaşamak için çalışıyorum. Sinemaya, tiyatroya gitmek için çalışıyorum. Arkadaşlarımla rahatça zaman geçirebilmek için çalışıyorum. Benim zevk olarak yaptığım bir şeyi aileme yük olarak taşıtmak istemiyorum." (G2, Kadın, İktisat).

"Kazancımı boş zamanlarımda bir şeyler yapmak için kullanıyordum. Kendime kıyafet almak için. Tabii ailemin biraz masrafın azaltmak için de..." (G15, Kadın, İktisat)

"Genç olamama hali" ise hem yoksul öğrencilerin tüketim kalıplarına ulaşamama hem de çalıştıkları için boş zamanlarında diğer gençler gibi çeşitli sosyal aktivitelere katılamama durumunu ifade etmektedir. Aslında "genç olamama hali" bir bakıma sosyal dışlanma ilişkisini de içermektedir:

"Mesela çoğu genç gibi her gece eğlenmeye çıkamam ya da her beğendiğimi alamam. Ailemi düşünmek zorundayım. Ama hiçbir şey de içimde kalmamıştır. Her şeyi yaşamaya çalışıyorum."(G16, Kadın, Gerontoloji)

"Temel ihtiyaçlarımı karşılayabiliyordum ama sosyal hayatım için daha iyi şartlar olması için çalışmayı istedim... Cebimde param var mı? Gidiyorum, ediyorum, içiyorum ama her zaman aklımda hep bir soru var. Rahat değilsin. İçtim ama param var mı? İçtim ama yetecek mi? Ayy ne yaptım ben! Bunu içeceğime başka bir yerde içseydim..."(G3, Kadın, Hemşirelik)

Söz konusu öğrenciler için boş zaman aktiviteleri oldukça kısıtlıdır veya hiç yoktur. Bunun nedeni boş zaman faaliyetlerinin ekonomik bir külfet yaratması ya da çalışıyor oldukları için zamanlarının kalmamasıdır:

"Ekonomik olarak yetersizim diğer insanlara baktı̆̆ımda ki, Akdeniz üniversitesindeyiz... Insanlar genelde dışarıdan yer öğrenci milleti hani, parası vardır cebinde. Sen her gün yiyemezsin. Haftada bir yersin, haftada iki yersin, kendini zorlarsan. Ekonomik olarak kendini krize sokmuş oluyorsun. Ha şöyle düşünürsün, o yiyor ben yiyemiyorum falan ama alışıyorsun yani bir müddet sonra." (G12, Erkek, Ekonometri) 
"Sosyallik açısından kendimi yetersiz hissediyorum. Mesela sinemaya gidemiyorum. Çünkü çalışıyorum hem vakit sıkıntı hem de çalıştı̆̆ımla böyle lüks şeyler yapamam." (G21, Erkek, Fen Bilgisi Öğretmenliği)

"Sosyal aktivitem olmuyor, boş kaldığım zamanlarda da çalıştığım için boş zamanım kalmıyor." (G18, Kadın, Bilgisayar Programcılı̆̆ı)

"Herkes tatil yapıyorken ben çalışıyorum." (G20, Erkek, Tarih)

"Kendimi diğer öğrencilerden farklı görüyorum, çalışıyor olmak sosyal faaliyetlere daha az vakit ayırmama neden olabiliyor ve bu durum bazen can sikıcı..." (G4, Kadın, Bilgisayar Programcılığı)

"Ekonomik yetersizlikler doğrultusunda bazen yapmak istediğim ya da olmak istediğim durumlarda olamıyorum." (G5, Kadın, Uluslararası İlişkiler)

Yoksulluk nedeniyle çalışmak zorunda kalan gençler, kendilerini aynı zamanda "genç" olarak görmemektedirler. Nihayetinde eğitim masraflarını karşılama noktasında birikim yapan, bunun için boş zamanlarında çalışan öğrenciler için tüketim toplumunun sunduğu "genç olma hali/gençlik imajı" pek bir anlam ifade etmemektedir.

- Işs deneyimi kazanma ve alternatif istihdam alanlarna yönelme stratejisi: Modern eğitim sistemleri, işgücü piyasası koşullarına uygun nitelikte bireyler yetiştirmeyi hedeflemektedir. Ancak hızlı toplumsal değişme örüntülerine ayak uyduramayan, bu nedenle giderek ağırlaşan ve statik hale gelen, dolayısıyla işgücü piyasasının taleplerine cevap veremeyen eğitim kurumları, eğitimciler ve yöneticiler bulunmaktadır. Kısacası eğitim sistemlerinin güncellenmesi gerekmektedir. Devlet memurluğunun önemsendiği Doğu toplumlarında, ebeveynler, çocuklarının iş garantisi, sosyal güvencesi ve sabit maaşı olan, diğer bir deyişle "masa başı bir devlet işinde" çalışmasını istemektedir. Dolayısıyla istihdam alanı oldukça dar, ancak mezun sayısı fazla olan bölümler, "devlet memuru" olma ihtimalini taşıdığı için tercih edilmektedir. Nihayetinde üniversite eğitimine başlayan bir öğrencinin, özellikle de mezun olma süreci yaklaştıkça, geleceği ile ilgili kaygıları artmaktadır:

"Belirsizlik içinde yaşıyoruz."(G19, Kadın, Felsefe)

"Ailenizin sizden bir beklentisi var, kaygı var. Kendimden çok kardeşlerimi düşünüyorum."(G17, Erkek, Felsefe)

"Okuduğum bölüm çok fazla mezun veriyor. İş bulabilmem için diğer öğrencilerden fark yaratmam gerek..." (G2, Kadın, İktisat) 
Gelecek kaygısı, yükseköğretim öğrencilerini eğitim süreçlerinde iş deneyimi kazanmaya ve alternatif istihdam alanlarında iş bulmaya yönlendirmektedir:

"İş ilanlarında deneyimli eleman istiyorlar, deneyim kazanmam da gerekiyor, ileri de bir iş istiyorum." (G18, Kadın, Bilgisayar Programcılığı)

Çalışma kapsamında öğrencilere, farklı bir bölümde eğitim almayı isteyip-istemedikleri sorusu yöneltilmiştir. Buna göre Hukuk Fakültesi, Diş Hekimliği Fakültesi gibi istihdam sıkıntısı olmayan ya da Eğitim Fakültesi, İktisadi ve İdari Bilimler Fakültesi gibi istihdam alanı dar olsa da, atanma ihtimali olan bölümlerde eğitim alan öğrenciler, eğitim aldıkları alanları benimsemiş görünmektedir:

"Hedefim mimarliktı. Çeoremdekiler öğretmen olup atama beklemektense, hemşire ol, illaki iş bulursun dediler." (G3, Kadın, Hemşirelik)

"Sağlık alanında eğitim görmek isterdim. İş garantisi var. Okuduğum bölümle ilgili gelecek kaygısı yaşıyorum." (G17, Erkek, Felsefe).

Diploma toplumunun inanc1, bireylerin kişisel bilgi ve becerileri ile değil, alınan diploma ile toplumsal statü kazandığıdır. Toplumsal bilince zerk edilen bu inanç, eğitim sistemi ile bireysel bilince kazınmakta, dolayısıyla birey, diploma olmadan, hayatta başarılı olamayacağını düşünmektedir. Ekonomik yetersizlikler ya da aile baskısı da, söz konusu toplumsal algıya eşlik ederek, kişileri istemedikleri alanlarda eğitim görmelerine neden olmaktadır. Örneklem grubumuzdaki gençlerin de, başarının bir ölçütü olarak diplomayı görmeleri, bu durumu kanıtlar niteliktedir. Öğrencilerin, gelecek kaygılarını bastırabilmek amacıyla eğitim aldıkları alandan farklı olarak, ancak genel itibariyle devlet memurluğu kapsamında değerlendirebileceğimiz istihdam alanlarına yöneldikleri görülmektedir.

"Okuduğum bölümden mezun olunca iş bulabileceğimi sanmıyorum, o yüzden polis olmayı düşünüyorum." (G20, Erkek, Tarih)

"Gelecekteki hedefim polis olmak, okuduğum bölümden iş bulabileceğimi sanmıyorum, özel harekât polisi, düz polis memurluğu da olabilir." (G22, Erkek, Felsefe)

"Okuduğum bölümde iş olanağ 1 yok denecek kadar az, bu yüzden inşaat sektöründe ilerlemek istiyorum." (G7, Erkek, Su Ürünleri Mühendisliği)

"Aslında son seneye kadar düşünmüyorum fakat mezun olmaya yakın tekrar sorguluyorsunuz, mesleğinizi, okuduğunuz bölümü. Bu konuda endişelerim var, 
emin değilim. Gelecekteki hedefim, sanırım akademik alanda ilerlemek. Son sinıfta aklıma düştü bu. Böyle bir geleceğim olur mu, bilmiyorum." (G16, Kadın, Gerontoloji)

"Akademik kariyer yapmak istiyorum."(G8, Erkek, Türkçe Öğretmenliği)

"Gelecekteki hedefim akademisyen olmak."(G12, Erkek, Ekonometri)

Polis ya da akademisyen olmak arasındaki bir seçim, öğrencinin kendisine olan güven duygusu ve akademik başarısı ile doğrudan ilişkilidir. Burada dikkati çeken konu, öğrencinin almış olduğu diploma ile iş bulma olasılığı düşüyorsa, bu durumda gençlerin söz konusu iki meslek grubundan birine doğru yönelmesidir. Görüldüğü üzere yükseköğretim öğrencilerinin birincil amacı devlet memurluğudur. Türkiye'nin gerçekleri düşünülünce, özellikle özel sektördeki istihdam koşulları dikkate alınınca (güvencesizlik, düşük ücret, uzun çalışma saatleri) bu isteğin anlaşılır olduğu görülmektedir.

\section{Sonuç ve değerlendirme}

Yükseköğretim öğrencilerinin yeterli ekonomik kaynaklara sahip olmaması, ayrıca kredi, burs, yurt gibi çeşitli destek mekanizmalarının yetersiz kalması nedeniyle; beslenme, barınma, ulaşım, sağlı gibi çeşitli alanlardaki temel ihtiyaçlarını karşılayamadığı ve eğitim yaşamlarını sürdürebilme noktasında problemler yaşadığı tespit edilmiştir. Mekânsal özelliklerin (kır-kent ya da bölgesel eşitsizlikler) yanı sıra ailenin sahip olduğu "kültürel ve ekonomik sermayenin hacmi ve kompozisyonuna" bağlı olarak, yükseköğretim öğrencilerinin istihdama dâhil oldukları görülmektedir. Öte yandan bazı öğrenciler ise ekonomik yetersizliklerinden dolayı değil, tüketim kalıplarına erişebilme ve boş zamanlarını değerlendirme imkânına sahip olabilme doğrultusunda çalıştıkları saptanmıştır.

Hem istihdamda hem de eğitimde olan öğrenciler için çalışmak; özgüveni yükseltmekte, sorumluluk bilincini aşılamakta ve deneyim kazanmalarını mümkün hâle getirmektedir. Ancak güvencesiz istihdam aynı zamanda çeşitli riskleri ve sembolik şiddete maruz kalmayı da beraberinde getirebilmektedir.

Gelişen ve esnekleşen işgücü piyasasına uygun birey yetiştirme hususunda, eğitim sisteminde görülen aksaklıklar, bireyler tarafından elde 
edilen diplomaların tartışılır bir hale gelmesine neden olmaktadır. Örneklem grubumuzdaki öğrencilerin eğitim gördükleri bölümlerin sayıca fazla mezun vermesi, buna karşın istihdam alanlarının dar olması, yükseköğretim öğrencilerinde okudukları bölümlerin sorgulanmasına ve gelecek kaygısını yoğun bir şekilde yaşamalarına neden olmaktadır.

Hem istihdamda hem de eğitimde yer alan yükseköğretim gençliğinin çalışma nedenleri ile ilgili olarak dört neden tespit edilmiştir: eğitim yaşamını devam ettirme, mutlak ve/veya göreli yoksulluklarıyla mücadele etme, tüketim alanın içinde olma ve sosyal dışlanmaya maruz kalmama, iş deneyimi kazanma ve alternatif istihdam alanlarına yönelme. Bu dört strateji, aynı zamanda Türkiye'nin eğitim sistemindeki problemlerini de özetlemektedir. Bu bakımdan "istihdam için mi eğitim?" yoksa "eğitim için mi istihdam?" sorusu, politika yapıcıların üzerinde durması gereken temel problematik alanlardan biridir. Nihayetinde esnekleşen ve gelişen işgücü piyasasına uygun bireyler yetiştirme; bölgesel ya da toplumsal cinsiyete dayalı eşitsizliklerin telafi edilmesi; maddi yetersizliklerden dolayı eğitime erişim sağlayamayan bireyler için imkânlar oluşturması; ayrıca genel anlamda eğitimde fırsat eşitliğini sağlayıcı mekanizmaların üretilmesi gibi eğitim sisteminin ve politikalarının gözden geçirilmesi ve güncelleme yapılması gerekliliği ortaya çıkmaktadir.

\section{Kaynakça}

Avrupa Komisyonu, Türkiye 2011 yıl ilerleme raporu, http://www.ab.gov.tr/files/AB Iliskileri/AdaylikSureci/IlerlemeRaporlari/2011_ilerleme raporu_tr.pdf, Erişim Tarihi: 19 Temmuz 2017.

Avrupa Komisyonu, Türkiye 2013 yıl ilerleme raporu, http://www.ab.gov.tr/files/2013\%20ilerleme\%20raporu/2013 ilerleme raporu tr.pdf, Erişim Tarihi: 19 Temmuz 2017.

Birchall, J. (1999). Organizing workers in the informal sector a strategy for trade union-cooperative action, Stable, http://www.oit.org/wcmsp5/groups/public/--- 
ed_emp/emp_ent/documents /publication/wcms_110508.pdf,

Erişim Tarihi: 14 Temmuz 2017.

Birleşmiş Milletler Kalkınma Programı (UNDP), Türkiye 2008 insani gelişme raporu: Türkiye'de gençlik, http://www.unicankara.org.tr/2008 March/NHDR tr.pdf, Erişim Tarihi: 20 Temmuz 2017.

Bocock, R. (2009). Tüketim, İ. Kutluk (Çev.), Ankara: Dost Yayınları.

Bolak Boratav, H. (2005). Negotiating youth: growing up in inner-city Istanbul, Journal of Youth Studies, 8 (2), 203-220.

Bourdieu, P. (1999). Understanding, Pierre Bourdieu (Ed.), The weight of the world: social suffering in contemporary society in (pp. 607-626), California: Stanford University Press.

Bourdieu, P. ve Passeron, J.C. (2005). Yeniden üretim: eğitim sistemine ilişkin bir teorinin ilkeleri, Aslı Sümer, Levent Ünsaldı ve Özlem Akkaya (Çev.), İstanbul: İletişim Yayınları.

Curtain, R. (2004). Youth in extreme poverty: dimensions and policy implications with particular focus on south East Asia, http://www.youthmetro.org/uploads/4/7/6/5/47654969/youth in extreme poverty south east asia.pdf, Erişim Tarihi: 17 Temmuz 2017.

Çelik, K. (2013). Genç olmak zor iş: Türkiye' de genç olmayı etkileyen bazı unsurlar, Gençlik Araştırmaları Dergisi, 11 (1), 26-45.

Çetinkaya, E. (2008). Türkiye'de gençlerin kayıt dişı istihdamdaki durumu, Bilgi Sosyal Bilimler Dergisi, 2, 115-125.

Ferreira F. H. G., Gignoux, J. (2010). Eğitimde fırsat eşitsizliği: Türkiye örneği, Türkiye Cumhuriyeti Devlet Planlama Teşkilatı ve Dünya Bankası Refah ve Sosyal Politika Analitik Çalışma Programı, Çalışma Raporu, 4, http://siteresources.worldbank.org/INTTURKEYINTURKISH/147254-1269017398324/22764932/EgitimdeFirsat Esitsizligi.pdf, Erişim Tarihi: 06 Temmuz 2017.

Grant, M. J., Furstenberg, F. F. (2007). Changes in the transition to adulthood in less developed countries, European Journal of Population, 23, 415-428.

International Labour Organization (ILO). (2015). Global employment trends for youth 2015, http://www.ilo.org/wcmsp5/groups/public/--dgreports/---dcomm/---publ/documents/publication/wcms 412015.pdf, Erişim Tarihi: 20 Temmuz 2017. 
İzdeş, Ö. (2010). Türkiye'de yoksulluk analiz ve tartışmalarına bir bakış, Ali Rıza Güngen ve diğerleri (Der.), Emek ve siyaset içinde (ss.207264), Ankara: Dipnot Yayınları.

Kahraman F., Kahraman A.B. (2016), Mevsimlik istihdamın eğitimli gençleri: inşaatlarda çalışan üniversite öğrencileri üzerine bir araştırma, SDÜ Fen Edebiyat Fakültesi Sosyal Bilimler Dergisi, 38, 183201.

Kazgan, G. (2002). Kuştepe gençliği araştırması, İstanbul: İstanbul Bilgi Üniversitesi Yayınları.

Kazgan, G. (2006). İstanbul gençliği: gençlik değerleri araştırması, İstanbul: İstanbul Bilgi Üniversitesi Yayınları.

Lüküslü, D. (2009). Türkiye'de gençlik miti: 1980 sonrası Türkiye gençliği, İstanbul: İletişim Yayınları.

McPake, J.,Bhatti, G. (1999). Education and poverty in Western Europe, Prospects, 29 (4), 551-559.

Organisation for Economic Co-operation and Development (OECD) (2016). society at a glance 2016, a spotlight on youth, how does Turkey compare?, https://www.oecd.org/turkey/sag2016-turkey.pdf, Erişim Tarihi: 19 Temmuz 2017.

Standing, G. (2015). Prekarya yeni tehlikeli sınıf, Ergin Bulut (Çev.), İstanbul: İletişim Yayınları.

Şahin, İ. ve diğerleri (2009). Üniversite öğrencilerinin sorunları, Education Sciences JF, 4 (4), 1435-1449.

Temiz, H. E. (2004). Eğreti istihdam: işgücü piyasasında güvencesizliğin ve istikrarsızlığın yeni yapılanması, Çalışma ve Toplum Dergisi, 2, 5580.

Türkiye İstatistik Kurumu (TÜİK) (2017). Eğitim İstatistikleri 2017 Net Okullaşma Oranları, www.tuik.gov.tr/PreIstatistikTablo.do?istab id=1606, Erişim Tarihi: 19 Temmuz 2017.

Türkiye İstatistik Kurumu (TÜİK) (2016). Gelir ve Yaşam Koşulları Araştırması 2015, http://www.tuik.gov.tr/PreHaberBultenleri.do?id=21584, Erişim Tarihi: 20 Temmuz 2017.

Türkiye İstatistik Kurumu (TÜIK) (2016). Gençlerin İşgücü Piyasasına Geçişi Araştırma Sonuçları 2015, http://www.tuik.gov.tr/PreHaberBultenleri.do?id=21865, Erişim Tarihi: 18 Temmuz 2017. 
Türkiye İstatistik Kurumu (TÜİK) (2016). İstatistiklerle Gençlik 2015, http://www.tuik.gov.tr/PreHaberBultenleri.do?id=21517, Erişim Tarihi: 17 Temmuz 2017.

Türkiye İstatistik Kurumu (TÜİK) (2017). İstatistiklerle Gençlik 2016, http://www.tuik.gov.tr/PreHaberBultenleri.do?id=24648, Erişim Tarihi: 17 Temmuz 2017.

Türkiye İstatistik Kurumu (TÜİK) (2017). İşgücü İstatistikleri 2017, http://www.tuik.gov.tr/HbGetirHTML.do?id=24629, Erişim Tarihi: 19 Temmuz 2017.

Türkiye İstatistik Kurumu (TÜİK) (2016). Yoksulluk Çalışması 2015, http://www.tuik.gov.tr/PreHaberBultenleri.do?id=21867, Erişim Tarihi: 20 Temmuz 2017.

World Bank (2016). Global monitoring Report 2015/2016: development goals in an era of demographic change, http://pubdocs.worldbank.org/en/503001444058224597/Global-Monitoring-

Report-2015.pdf, Erişim Tarihi: 20 Temmuz 2017.

Uyan Semerci, P. (2008). Çocuktan yetişkine: genç olamayanlar, Nurhan Yentürk, Yörük Kurtaran ve Gülesin Nemutlu (Der.), Türkiye'de gençlik çalışması ve politikaları içinde (ss. 401-417), İstanbul: İstanbul Bilgi Üniversitesi Yayınları.

Wyn, J., White R. (1997). Rethinking youth, Sydney: Allen\&Unwin.

Yamanoğlu, M. A. (2010), Tüketim toplumunda genç ve yoksul olmak, Kültür ve İletişim Dergisi, 13 (2), 41-79.

Zorlu, A. (2006). Modern Tüketimin Tarihinden Tüketim Araştırmalarına Tüketim Sosyolojisi, Ankara: Glocal Yayınları.

\section{Kaynakça Bilgisi / Citation Information}

Aygül, H. H. (2018). Eğitime Erişim, Yoksulluk ve Formel/Enformel İşgücü Olarak Üniversite Gençliği: “İstihdam İçin mi Eğitim? Eğitim İçin mi İstihdam?". OPUS - Uluslararası Toplum Araştırmaları Dergisi, 8(Gençlik Araştırmaları Özel Sayısı), 58-87. 